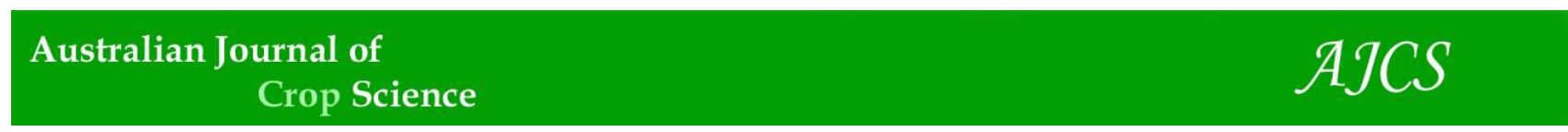

AJCS 10(8):1083-1091 (2016)

ISSN:1835-2707

DOI: $10.21475 /$ ajcs.2016.10.08.p7179

\title{
Effects of conventional and organic farming systems on bio-agronomic and quality traits of durum wheat under Mediterranean conditions
}

\author{
Anna Iannucci* and Pasquale Codianni
}

Council for Agricultural Research and Economics, Cereal Research Centre (CREA-CER), S.S. 673, Km 25,200, 71122 Foggia, Italy

*Corresponding author: anna.iannucci@crea.gov.it

\begin{abstract}
The effects of conventional and organic farming systems on 10 durum wheat (Triticum durum Desf.) cultivars were studied over a 3year period (2012-2014) in Foggia (southern Italy). The aim was to compare their agronomic and qualitative characteristics, and to test their adaptability and stability to these different management practices in terms of seed yield. The experiment followed a splitplot design, with three replications in each year. Six traits were investigated: heading time, plant height, seed yield, test weight, 1000seed weight, and protein content. The data from the analysis of variance indicated that there were significant differences between years, cropping systems, and genotypes for all of these characteristics. The mean seed yield for the organic system was $40 \%$ lower than that of the conventional system. The wheat quality was affected by cultivation management, with protein content $19 \%$ higher under the conventional system. The highly significant differences found for the genotype $\times$ environment interaction of the seed yield indicated the possibility to choose the stable genotypes across environments. Three univariate $\left(b, S^{2} \mathrm{~d}, \mathrm{R}^{2}\right)$ and two multivariate (additive main effect and multiplicative interaction stability value, yield stability index) stability statistics were used. Based on these analyses, the varieties 'Iride' and 'Saragolla' showed high-stability responses and good seed yield under both farming systems. Therefore, these can be recommended for less fertile environments, such as organic farming systems in Mediterranean areas. On the contrary, the genotype 'Anco Marzio' was well adapted for high seed yield in more fertile environments.
\end{abstract}

Keywords: conventional cultivation; organic cultivation; $\mathrm{G} \times \mathrm{E}$ interaction; seed yield; seed quality; Triticum durum Desf.

Abbreviations: AMMI_additive main effect and multiplicative interaction; ANOVA_ analysis of variance; ASV_ammi stability value; $b_{-}$regression coefficient; $\mathrm{CS}_{-}$cropping system; $\mathrm{G}$ x E_ genotype x environment; IPCA_ interaction principal component axes; PCA_ principal component analysis; $\mathrm{R}_{2}^{2}$ coefficient of determination; $S^{2} \mathrm{~d}_{-}$deviation from regression line; YSI _yield stability index.

\section{Introduction}

Durum wheat (Triticum durum Desf.) is the most widespread crop in the Mediterranean environment, which is characterized by water stress and high temperatures during the late spring and summer seasons (Araus et al., 2002). Durum wheat is an economically important crop because of its unique characteristics and end-use products, which include pasta, couscous, and flat bread (Mohammadi et al., 2010). According to United Nations Food and Agricultural Organization statistics of 2013, the acreage of durum wheat in Italy was about 1.3 million ha, which yielded 4 million tons of seed. This durum wheat production is concentrated in the southern regions of Italy (about 67\%), and is mainly used for pasta (D'Egidio, 2007).

The alternation of durum wheat and fallow (i.e., one crop every 2 years) remains the conventional cropping system today for continuous wheat production in these areas. This term 'conventional' refers to the high-input, intensive farming system that is based on the use of chemical fertilizers for immediate availability of nutrients and primarily for use with high-value crops. However, indiscriminate and continuous use of such chemical fertilizers reduces the soil health, especially because of micronutrient deficiency and environmental pollution (Murmu et al., 2013).

Organic farming represents another viable option to reduce the environmental impact of this cereal production. In recent years, the acreage of durum wheat under organic farming systems has been constantly growing, which follows the increased demand from consumers, who have become more aware of the potential benefits of organic farming in terms of environmental safety and human health (Willer and Yussefi, 2007). Organic farming avoids the use of synthetic fertilizers, pesticides, and plant-growth regulators, and its main objective is to reduce the use of non-renewable resources and the environmental degradation, while maintaining productivity and profitability (Wheeler, 2008). Despite these positive aspects, several studies have highlighted low productivity and reduced efficiency in terms of resources use under this alternative form of agricultural management, as compared to conventional farming (Bulluck et al., 2002; Trewavas, 2004; Kramer et al., 2006). As suggested by Lammerts van Bueren et al. (2011), this is probably because the organic farming systems have used poorly adapted cultivars that have been selected by plant breeders for use 
under conventional systems. However, as there is little chance of an immediate response to this problem, there is the need to investigate the adaptation of the varieties that are already available, in terms of the different environmental conditions that occur under organic farming. Thus, trials conducted across a range of environments within these different farming systems and over multiple years will be needed to provide the information for specific adaptation of the genotypes in target areas. In particular, such field experiments allow the identification of tolerant cultivars that have the characteristics of stability and adaptability under such low-input conditions, in terms of both seed yield and grain quality.

The performance of conventionally grown durum wheat varieties is often different in other environments with lower inputs, due to genotype $\times$ environment $(\mathrm{G} \times \mathrm{E})$ interactions (Wolfe et al., 2008). An ideal variety should have a high mean yield combined with a low degree of fluctuation when grown in different environments. This stability has been classified into two main concepts: static and dynamic. Static stability is characterized by constant genotype performance under different environmental conditions, while dynamic stability is characterized by the performance of a given genotype compared with the environmental mean (Becker and Leon, 1988).

Several biometric methods have been proposed to analyze $\mathrm{G} \times \mathrm{E}$ interactions, to determine the stability of performance. These have ranged from univariate parametric analyses, such as the regression slope value (Finlay and Wilkinson, 1963), deviation from regression (Eberhart and Russell, 1966), and the coefficient of determination (Pinthus, 1973), to multivariate methods, such as additive main effect and multiplicative interaction (AMMI) analysis (Zobel et al., 1988). As the success of a new wheat variety depends upon its yield and adaptation potential under different cropping systems, it is important to evaluate the degree of its interaction with diverse environments, to be able to select promising genotypes to recommend to farmers.

The objectives of the present study were: (i) to determine the effects of the conventional and organic management systems on the main agronomical traits and grain quality of 10 durum wheat cultivars over a three-year period; and (ii) to evaluate the phenotypic stability under the conventional and organic systems of cultivation to determine whether recent varieties are well adapted to organic farming systems.

\section{Results}

\section{Analysis of variance and agronomic performance}

The results of the analysis of variance showed highly significant differences for years (Y), cropping systems (CS), and genotypes $(\mathrm{G})$, and for the relative interactions between all of the traits examined, with the exception of the $\mathrm{G} \times \mathrm{CS}$ interaction for plant height (Table 2). Under organic management compared to conventional farming, the 10 genotypes showed yearly means for plant height, seed yield, and protein content that were $4 \%, 40 \%$, and $19 \%$ lower, respectively, while for heading time, test weight, and seed weight, these were $6 \%, 2 \%$, and $10 \%$ higher, respectively. Mean seed yield varied across the growing seasons, with 2014 producing the highest $\left(4.2 \mathrm{t} \mathrm{ha}^{-1}\right)$ and 2012 the lowest $\left(2.9 \mathrm{t} \mathrm{ha}^{-1}\right)$. The highest mean yields were obtained for 'Anco Marzio' (4.03 t ha ${ }^{-1}$ ), 'Claudio' (3.88 t ha ${ }^{-1}$ ), 'Saragolla' (3.79 $\left.\mathrm{t} \mathrm{ha}^{-1}\right)$, and 'Iride' $\left(3.74 \mathrm{t} \mathrm{ha}^{-1}\right)$, while the lowest were obtained for 'Aureo' and 'Tirex' (3.16 t ha $\left.{ }^{-1}\right)$. Furthermore, heading time for 'Dylan' was late (26.7 days from April 1), whereas for 'Saragolla' it was early (20.3 days from April 1), with a mean difference of $>6$ days. High variation was also found for plant height: 'Simeto' was the shortest $(75 \mathrm{~cm})$, while 'Anco Marzio', 'Aureo', and 'Claudio' were the tallest (mean, $83 \mathrm{~cm}$ ). The technological and nutritional quality was also influenced by both the growing season and the genotype. The grain protein content was highest in 2012 (13.3\%) and lowest in 2013 (12.4\%), and 'Aureo' and 'Anco Marzio' were the highest and the lowest, respectively. Test weight, which is a measure of cereal kernel quality, ranged from 79.9 $\mathrm{kg} \mathrm{hL}{ }^{-1}$ ('Simeto') to $83.8 \mathrm{~kg} \mathrm{hL}^{-1}$ ('Anco Marzio', 'Claudio'). Furthermore, mean 1000-seed weight ranged from 'Duilio' and 'Simeto' as the highest (mean, $48.1 \mathrm{~g}$ ) to 'Tirex' as the lowest (39.7 g).

\section{Phenotypic correlation}

The pair-wise correlations among all of the traits were highly significant, and showed the same sign for both management systems between heading time and plant height (negative) and test weight (positive), and between plant height and test weight (negative) (Table 3). The other characters showed different associations in relation to the type of cultivation. In particular, there were highly significant positive and negative correlations $(\mathrm{r}=1.00 * * ; \mathrm{r}=-1.00 * *)$ between seed yield and protein content for the organic and conventional management systems, respectively. For the organic system, seed yield had positive correlation with plant height $\left(\mathrm{r}=0.81^{* *}\right)$, and negative correlation with heading time $(\mathrm{r}=-0.78 * *)$.

\section{AMMI analysis for seed yield}

The combined ANOVA for grain yield showed that $5 \%$ of the total variability was explained by genotype $(\mathrm{G}), 81 \%$ by environment (E), and $12 \%$ by the $\mathrm{G} \times \mathrm{E}$ interaction (Table 4 ). The $\mathrm{G} \times \mathrm{E}$ effect was 2.5 -fold greater than the $\mathrm{G}$ effect, which indicated that there were differences in the genotypic responses across the environments. As the first four interaction principal component axes (IPCAs) explained 99\% of the $\mathrm{G} \times \mathrm{E}$ sum of squares, this showed that the AMMI model was more appropriate to explain the $\mathrm{G} \times \mathrm{E}$ interactions.

\section{Comparison of yield stability parameters}

The presence of clear interactions between the studied genotypes and the growing conditions allowed significant assessment of the stability and adaptability for the seed-yield trait. The five stability statistics (i.e., $b, S^{2} \mathrm{~d}, \mathrm{R}^{2}, \mathrm{ASV}, \mathrm{YSI}$ ) were compared for their ranking of the genotypes (Table 5). The $b$ values for the 10 genotypes tested ranged between 0.71 ('Aureo') and 1.37 ('Anco Marzio'), while the $S^{2}$ d values ranged between 0.07 ('Iride') and 4.49 ('Anco Marzio'). According to Eberhart and Russell (1996), a wide adaptability genotype is defined as one with $b=1.0$, and high stability as one with $S^{2} \mathrm{~d}=0$. Thus, in the present study, 'Dylan' and 'Iride' were the most stable cultivars, because they showed both $b$ close to 1.0 (i.e., $1.09,0.83$, respectively) and relatively low deviation values (i.e., 0.28, 0.07, respectively). In contrast, 'Anco Marzio' can be regarded as sensitive to environmental changes. The coefficient of determination $\left(\mathrm{R}^{2}\right)$, which is a measure of the variation of the mean grain yield explained by the genotype response across environments, ranged from 0.78 ('Anco Marzio') to 0.99 ('Iride'). The ASV is the distance from the coordinate point to the origin in a two-dimensional graph of IPCA1 scores against IPCA2 scores in the AMMI model (Purchase et al., 
Table 1. Environmental data at Foggia (Italy) over the three growing seasons (2012-2014), including the long-term (15-year) means.

\begin{tabular}{|c|c|c|c|c|c|c|c|c|c|c|c|c|}
\hline \multirow[t]{2}{*}{ Month } & \multicolumn{4}{|c|}{$\begin{array}{l}\text { Maximum temperature } \\
\left({ }^{\circ} \mathrm{C}\right)\end{array}$} & \multicolumn{4}{|c|}{$\begin{array}{l}\text { Minimum temperature } \\
\left({ }^{\circ} \mathrm{C}\right)\end{array}$} & \multicolumn{4}{|l|}{$\begin{array}{l}\text { Rainfall } \\
(\mathrm{mm})\end{array}$} \\
\hline & 2011-12 & $2012-13$ & 2013-14 & $\begin{array}{l}15 \text {-year } \\
\text { mean }\end{array}$ & 2011-12 & $2012-13$ & 2013-14 & $\begin{array}{l}15 \text {-year } \\
\text { mean }\end{array}$ & 2011-12 & $2012-13$ & 2013-14 & $\begin{array}{l}15 \text {-year } \\
\text { mean }\end{array}$ \\
\hline November & 17.7 & 21.7 & 16.6 & 18.0 & 2.0 & 5.9 & 9.0 & 8.5 & 52 & 69 & 78 & 64 \\
\hline December & 17.8 & 16.6 & 13.2 & 13.6 & -1.4 & -0.7 & 2.2 & 6.9 & 23 & 74 & 79 & 71 \\
\hline January & 15.6 & 15.8 & 13.5 & 13.2 & -2.7 & -1.0 & 5.1 & 4.4 & 36 & 43 & 25 & 63 \\
\hline February & 15.2 & 15.1 & 15.1 & 14.3 & -3.3 & -2.4 & 6.0 & 4.0 & 66 & 60 & 57 & 34 \\
\hline March & 22.5 & 20.6 & 16.3 & 17.2 & 2.1 & -1.8 & 3.9 & 5.8 & 46 & 30 & 23 & 50 \\
\hline April & 23.8 & 23.6 & 18.6 & 20.6 & 2.6 & 2.4 & 7.2 & 8.3 & 68 & 17 & 83 & 54 \\
\hline May & 29.0 & 27.2 & 22.6 & 26.5 & 6.8 & 8.6 & 10.1 & 12.5 & 25 & 58 & 44 & 32 \\
\hline June & 37.7 & 35.3 & 29.0 & 31.5 & 13.6 & 11.5 & 14.8 & 16.4 & 7 & 5 & 57 & 45 \\
\hline Mean & 22.4 & 22.0 & 18.1 & 19.4 & 2.4 & 2.8 & 7.3 & 8.3 & & & & \\
\hline Total & & & & & & & & & 321 & 355 & 446 & 412 \\
\hline
\end{tabular}
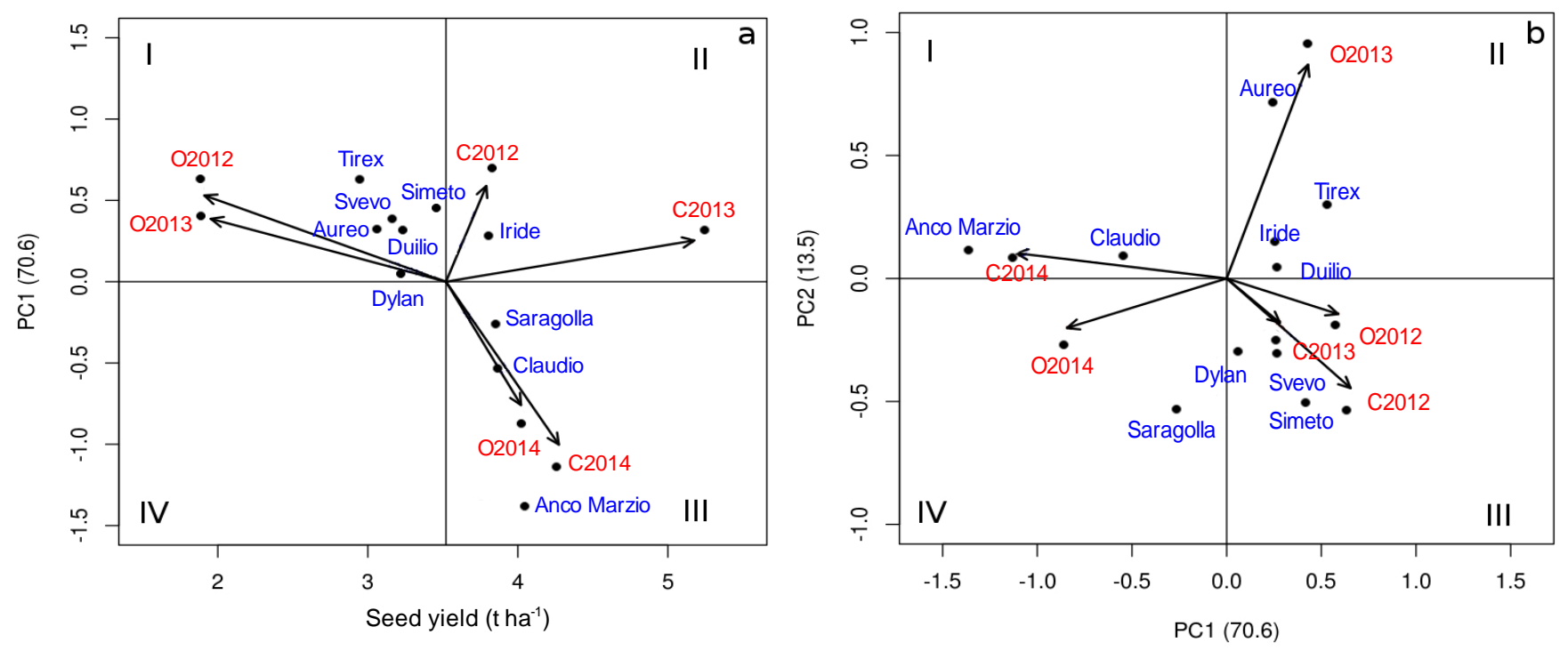

Fig 1. Biplots of the first interaction principal component axis (IPCA1) versus mean seed yield (a), and the IPCA1 versus IPCA2 for the 10 durum wheat genotypes across the six environments. 


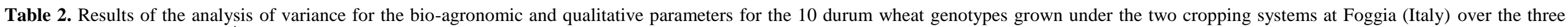
growing seasons (2012-2014) ${ }^{\dagger}$.

\begin{tabular}{|c|c|c|c|c|c|c|c|}
\hline Factor & Parameter/Interaction & Heading time (days from April 1) & Plant height $(\mathrm{cm})$ & Seed yield $\left(\mathrm{t} \mathrm{ha}^{-1}\right)$ & Test weight $\left(\mathrm{kg} \mathrm{hL}^{-1}\right)$ & 1000-seed weight $(\mathrm{g})$ & Protein content $(\%)$ \\
\hline \multirow[t]{3}{*}{ Year $(\mathrm{Y})$} & $2011-2012$ & $23.6 \mathrm{~b}$ & $73.5 \mathrm{c}$ & $2.85 \mathrm{c}$ & $85.5 \mathrm{a}$ & $39.7 \mathrm{c}$ & $13.3 \mathrm{a}$ \\
\hline & 2012-2013 & $25.6 \mathrm{a}$ & $76.8 \mathrm{~b}$ & $3.57 \mathrm{~b}$ & $85.4 \mathrm{a}$ & $49.3 \mathrm{a}$ & $12.4 \mathrm{c}$ \\
\hline & 2013-2014 & $16.7 \mathrm{c}$ & $87.9 \mathrm{a}$ & $4.15 \mathrm{a}$ & $75.6 \mathrm{~b}$ & $42.6 \mathrm{~b}$ & $13.1 \mathrm{~b}$ \\
\hline \multirow[t]{3}{*}{ Cropping system (CS) } & Organic & $22.5 \mathrm{a}$ & $77.7 \mathrm{~b}$ & $2.63 \mathrm{~b}$ & $83.1 \mathrm{a}$ & $45.9 \mathrm{a}$ & $11.6 \mathrm{~b}$ \\
\hline & Conventional & $21.3 \mathrm{~b}$ & $81.1 \mathrm{a}$ & $4.41 \mathrm{a}$ & $81.3 \mathrm{~b}$ & $41.9 \mathrm{~b}$ & $14.3 \mathrm{a}$ \\
\hline & Decrease $(\%)^{\ddagger}$ & +5.6 & -4.2 & -40.4 & +2.2 & +9.5 & -18.9 \\
\hline \multirow[t]{11}{*}{ Genotype (G) } & Anco Marzio & $23.4 \mathrm{~b}$ & $82.2 \mathrm{ab}$ & $4.03 a$ & $83.8 \mathrm{a}$ & $42.5 \mathrm{~d}$ & $12.6 \mathrm{~h}$ \\
\hline & Aureo & $22.1 \mathrm{~cd}$ & $82.2 \mathrm{ab}$ & $3.16 \mathrm{e}$ & $81.5 \mathrm{~d}$ & $42.9 \mathrm{~cd}$ & $13.4 \mathrm{a}$ \\
\hline & Claudio & $22.3 \mathrm{c}$ & $83.9 \mathrm{a}$ & $3.88 \mathrm{ab}$ & $83.7 \mathrm{a}$ & $45.3 \mathrm{~b}$ & $12.6 \mathrm{gh}$ \\
\hline & Duilio & $20.6 \mathrm{fg}$ & $78.9 \mathrm{de}$ & $3.36 \mathrm{~cd}$ & $81.8 \mathrm{~cd}$ & $47.7 \mathrm{a}$ & $13.1 \mathrm{~b}$ \\
\hline & Dylan & $26.7 \mathrm{a}$ & $80.0 \mathrm{~cd}$ & $3.32 \mathrm{cde}$ & $83.1 \mathrm{~b}$ & $44.5 \mathrm{bc}$ & $12.9 \mathrm{def}$ \\
\hline & Iride & $21.7 \mathrm{~d}$ & 76.9ef & $3.74 \mathrm{~b}$ & $82.3 \mathrm{c}$ & $42.4 \mathrm{~d}$ & $12.9 \mathrm{def}$ \\
\hline & Saragolla & $20.3 \mathrm{~g}$ & $76.1 \mathrm{fg}$ & $3.79 b$ & $81.7 \mathrm{~d}$ & $43.0 \mathrm{~cd}$ & $12.8 \mathrm{fg}$ \\
\hline & Simeto & $21.2 \mathrm{e}$ & $74.7 \mathrm{~g}$ & $3.49 \mathrm{c}$ & $79.9 \mathrm{e}$ & $48.4 \mathrm{a}$ & $13.0 \mathrm{bcd}$ \\
\hline & Svevo & $20.1 \mathrm{~g}$ & $81.7 \mathrm{bc}$ & $3.28 \mathrm{de}$ & $82.3 \mathrm{c}$ & $42.5 \mathrm{~d}$ & $13.0 \mathrm{bcd}$ \\
\hline & Tirex & $20.9 \mathrm{ef}$ & $77.5 \mathrm{ef}$ & $3.16 \mathrm{e}$ & $81.9 \mathrm{~cd}$ & $39.7 \mathrm{e}$ & $13.1 \mathrm{bc}$ \\
\hline & Mean & 21.9 & 79.4 & 3.52 & 82.2 & 43.9 & 12.9 \\
\hline \multirow[t]{7}{*}{$\operatorname{LSD}(\mathrm{P} \leq 0.05)$} & $\mathrm{Y}$ & 0.29 & 1.21 & 0.10 & 0.32 & 0.89 & 0.10 \\
\hline & $\mathrm{CS}$ & 0.23 & 0.98 & 0.08 & 0.26 & 0.73 & 0.08 \\
\hline & $\mathrm{Y} \times \mathrm{CS}$ & 0.41 & 1.70 & 0.14 & 0.45 & 1.63 & 0.14 \\
\hline & G & 0.53 & 2.20 & 0.18 & 0.58 & 1.26 & 0.17 \\
\hline & $Y \times G$ & 0.91 & 3.81 & 0.31 & 1.00 & 2.82 & 0.30 \\
\hline & $\mathrm{CS} \times \mathrm{G}$ & 0.74 & NS & 0.25 & 0.82 & 2.30 & 0.25 \\
\hline & $\mathrm{Y} \times \mathrm{CS} \times \mathrm{G}$ & 1.29 & NS & 0.43 & 1.42 & 3.98 & 0.43 \\
\hline
\end{tabular}

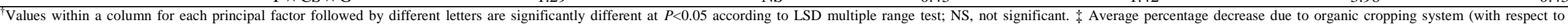
conventional plots).

Table 3. Phenotypic correlation coefficients (r) between the all of the traits for the 10 durum wheat genotypes grown organically (above diagonal) and conventionally (below diagonal) at Foggia (Italy) over the three growing seasons (2012-2014). ( $n=30)$.

\begin{tabular}{|c|c|c|c|c|c|c|}
\hline Character & $\begin{array}{l}\text { Heading time } \\
\text { (d) }\end{array}$ & $\begin{array}{l}\text { Plant height } \\
(\mathrm{cm})\end{array}$ & $\begin{array}{c}\text { Seed yield } \\
\left(\mathrm{t} \mathrm{ha}^{-1}\right)\end{array}$ & $\begin{array}{l}\text { Test weight } \\
\left(\mathrm{kg} \mathrm{hL}^{-1}\right)\end{array}$ & 1000 -seed weight $(\mathrm{g})$ & Protein content $(\%)$ \\
\hline Heading time (d) & 1 & $-0.69 * *$ & $-0.78 * *$ & $0.81 * *$ & 0.32 & $-0.78 * *$ \\
\hline Plant height $(\mathrm{cm})$ & $-0.61 * *$ & 1 & $0.81 * *$ & $-0.84 * *$ & 0.01 & $0.81 * *$ \\
\hline Seed yield $\left(\mathrm{t} \mathrm{ha}^{-1}\right)$ & 0.27 & 0.14 & 1 & $-0.81 * *$ & 0.04 & $1.00 * *$ \\
\hline Test weight $\left(\mathrm{kg} \mathrm{hL}^{-1}\right)$ & $0.93 * *$ & $-0.66^{* *}$ & 0.34 & 1 & -0.01 & $-0.81 * *$ \\
\hline 1000 -seed weight (g) & 0.25 & -0.03 & $0.90 * *$ & $0.37 *$ & 1 & 0.04 \\
\hline Protein content $(\%)$ & -0.27 & -0.14 & $-1.00 * *$ & -0.34 & $-0.90 * *$ & 1 \\
\hline
\end{tabular}




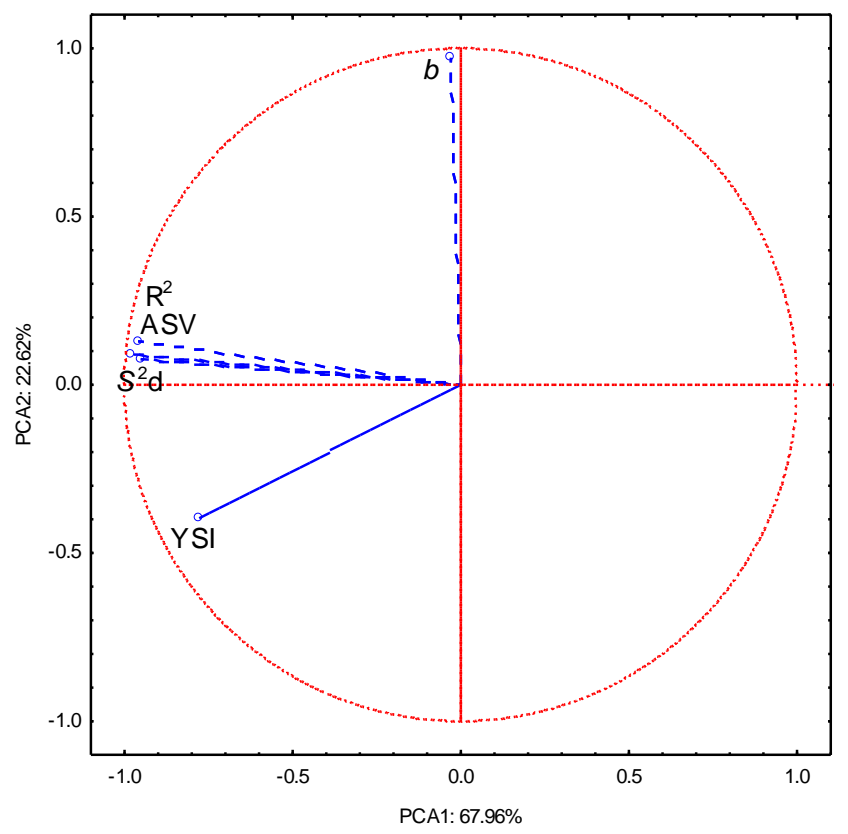

Fig 2. Principal component analysis (PCA1, PCA2) plot of the ranks of five yield-stability statistics estimated for the 10 durum wheat genotypes across the six environments.

2000). The genotype with the lowest ASV score is the most stable; accordingly, genotypes 'Dylan', 'Iride' and 'Duilio', followed by 'Saragolla', were the most stable. Furthermore, because the most stable genotypes would not necessarily give the best yield performance, the YSI was calculated, which takes into account both yield and yield stability (Mohammadi et al., 2007; Mohammadi and Amri, 2008). The lowest YSI is considered as the most stable with high grain yield. Based on this YSI, the most stable genotypes with high grain yield are 'Iride', 'Dylan' and 'Saragolla', which is in agreement with the AMMI stability value.

\section{Identify high yielding stable genotypes}

According to the AMMI analysis, it is possible to construct two biplots: (i) AMMI1 - Means versus IPCA1; and (ii) AMMI2 - IPCA1 versus IPCA2 (Fig. 1a, b). The biplot graphics analyse the dispersion of the genotypes and environments, and the interactions between them. The closer the IPCA scores are to zero, the more stable the genotypes are across their testing environments. When a genotype and environment have the same sign on the PCA axis, their interaction is positive, and if they have different signs, their interaction is negative. According to the AMMI model, the genotypes that are characterized by means greater than the overall mean and an IPCA score near zero are considered as generally adaptable to all environments. However, a genotype with high mean performance and with a large IPCA score is considered as having specific adaptability to the environments.

In Figure 1a, the points for the environments are more scattered than the points for the genotypes, which indicates that the variability due to the environments is higher than that due to the genotype differences, which is in agreement with the ANOVA. All of conventional cropping systems (Fig. 1a, C2012, C2013, C2014) are on the right-hand side of the midpoint of the main effect axis, and thus they appear to be favourable environments. Also, the organic system in 2014
(Fig. 1a, O2014) was favourable due to the particular climatic trend recorded in 2014. The cultivars 'Aureo', 'Duilio', 'Dylan', 'Iride', 'Saragolla', and 'Svevo' had low scores, which ranged from 0.2886 to -0.2236 , and contributed less to the $\mathrm{G} \times \mathrm{E}$ interaction (Fig. 1a). Among these entries, 'Iride' and 'Saragolla' showed high grain-yield main effects, with $3.74 \mathrm{t} \mathrm{ha}^{-1}$ and $3.79 \mathrm{t} \mathrm{ha}^{-1}$, respectively. Among the remaining entries, because of their large IPCA1 scores, genotypes 'Claudio' and 'Anco Marzio' are not stable and are specifically adapted to environments without limited water resources (Fig. 1a, O2014, C2014, respectively). Neither genotypes nor environments fell into the fourth quadrant, which refers to poorly fertile environments and to low yielding genotypes.

For the yield, the first two IPCAs explained $84 \%$ of the original $G \times E$ interaction variability (Fig. 1b). The two cropping systems showed different $\mathrm{G} \times \mathrm{E}$ patterns for the different years. The lengths of the vectors from the origin reflect the levels of interaction; thus, genotypes 'Anco Marzio' and 'Aureo', and the environments of the organic cropping system in 2013 and the conventional cropping system in 2014 (Fig. 1b, O2013, C2014) had the greatest effects in the $\mathrm{G} \times \mathrm{E}$ interaction. 'Duilio' and 'Iride' had the lowest scores, which indicates minimal $\mathrm{G} \times \mathrm{E}$ interaction effects. Therefore, they can be grown in all of the locations where the study was carried out.

\section{Principal components}

The relationships among the different stability parameters are shown graphically in a biplot of PCA1 and PCA2 (Fig. 2). PCA1 and PCA2 justify $96 \%$ of the total variation, and mainly define the statistics as three groups. Group 1 refers to the regression coefficient $b$, group 2 consists of the YSI, which defines genotypes 'Iride', 'Dylan', and 'Saragolla' as stable, and group 3 includes three indices (i.e., $S^{2} \mathrm{~d}, \mathrm{R}^{2}, \mathrm{ASV}$ ) that mainly distinguish 'Duilio', 'Dylan', and 'Iride' as stable genotypes. These last methods were highly and positively 
Table 4. Additive main effect and multiplicative interaction (AMMI) analysis of variance for seed yield ( $\mathrm{t} \mathrm{ha} \mathrm{h}^{-1}$ ).

\begin{tabular}{llllll}
\hline Source & df & Sum of squares & Mean of squares & F-value & $\begin{array}{l}\text { Variation } \\
\text { explained }(\%)\end{array}$ \\
\hline Total & 179 & 323.17 & & & 100.00 \\
Environments (E) & 5 & 260.55 & 52.11 & $295.66^{* *}$ & 80.62 \\
Reps within E & 12 & 2.12 & 0.18 & $2.89^{* *}$ & 0.01 \\
Genotype (G) & 9 & 15.93 & 1.77 & $29.02^{* *}$ & 4.90 \\
G E & 45 & 37.99 & 0.84 & $13.84^{* *}$ & 11.76 \\
IPCA 1 & 13 & 26.82 & 2.06 & $33.83^{* *}$ & $70.60^{\ddagger}$ \\
IPCA 2 & 11 & 5.14 & 0.47 & $7.66^{* *}$ & 13.51 \\
IPCA 3 & 9 & 4.33 & 0.48 & $7.89^{* *}$ & 11.42 \\
IPCA 4 & 7 & 1.31 & 0.19 & $3.08^{* *}$ & 3.50 \\
Residual & 108 & 6.59 & 0.06 & & \\
\hline
\end{tabular}

"IPCA, Interaction principal component analysis axis.

${ }^{\dagger}$ Percentage explained by ICPAs from that explained by $\mathrm{G} \times \mathrm{E}(11.8)$

$*, * *$ : Significant at 0.05 and 0.01 probability level, respectively.

Table 5. Various yield-stability analyses and relative rank (in parentheses) for the 10 durum wheat genotypes grown under the two cropping systems at Foggia (Italy) over the three growing seasons (2012-2014).

\begin{tabular}{lccccc}
\hline Genotype & $\mathrm{b}^{\dagger}$ & $S^{2} \mathrm{~d}$ & $R^{2}$ & ASV & YSI \\
\hline Anco Marzio & $1.37(10)$ & $4.49(10)$ & $0.78(10)$ & $3.13(10)$ & $11(6)$ \\
Aureo & $0.71(9)$ & $0.44(5)$ & $0.91(6)$ & $0.97(6)$ & $16(9)$ \\
Claudio & $1.09(7)$ & $1.01(8)$ & $0.91(7)$ & $1.19(8)$ & $10(5)$ \\
Duilio & $0.91(6)$ & $0.38(3)$ & $0.95(5)$ & $0.58(3)$ & $9(4)$ \\
Dylan & $1.09(5)$ & $0.28(2)$ & $0.97(2)$ & $0.27(1)$ & $8(2)$ \\
Iride & $0.83(8)$ & $0.07(1)$ & $0.99(1)$ & $0.58(2)$ & $6(1)$ \\
Saragolla & $1.09(4)$ & $0.57(6)$ & $0.95(4)$ & $0.70(4)$ & $8(3)$ \\
Simeto & $0.93(2)$ & $0.98(7)$ & $0.89(8)$ & $1.08(7)$ & $12(7)$ \\
Svevo & $1.04(1)$ & $0.42(4)$ & $0.96(3)$ & $0.73(5)$ & $12(8)$ \\
Tirex & $0.93(3)$ & $1.43(9)$ & $0.84(9)$ & $1.35(9)$ & $18(10)$ \\
\hline
\end{tabular}

${ }^{t} b$, regression coefficient; $S^{2} \mathrm{~d}$, deviation from regression line; $\mathrm{R}^{2}$, coefficient of determination; ASV, AMMI stability value; YSI, yield stability index.

associated among themselves, and they classify the genotypes as stable or unstable in similar manners. Consequently, only one of these statistics would be sufficient for the selection of stable genotypes.

\section{Discussion}

In the present study, most of the traits assessed showed significant $\mathrm{G} \times \mathrm{CS}$ and $\mathrm{G} \times$ yield interactions, which indicate that both the cropping management and climatic conditions significantly influenced the performance of the yield and the yield components of the durum wheat. Therefore, according to Mikò et al. (2014), and with the exception of plant height, these traits are efficient indicators for examining the differences between the performances of the varieties grown under organic and conventional cropping conditions.

Our data show that within each cropping system, the major differences in seed yield among the years were associated with the rainfall in critical months (i.e., especially in March, April and May) and with the temperatures. Ray et al. (2015) reported that in Italy the climate variability explained $31 \%$ to $51 \%$ of the wheat yield variability. However, a yield gap between the organic and conventional production systems confirmed the results reported for wheat in other field experiments, where differences have been identified depending on site, year and management system used (De Vita et al., 2007a; Murphy et al., 2007; Quaranta et al., 2010; Stagnari et al., 2013). Also, Fagnano et al. (2012) reported that production of durum wheat is mainly affected by the different responses of the cultivars to the lower $\mathrm{N}$ availability as a result of the organic cropping system, and so the choice of an adaptable genotype can allow satisfactory results to be achieved in terms of yield amount and grain quality. Indeed, the protein content, which is a primary quality component of cereal grains, was influenced the most by the management regime, with an evident decrease under organic conditions. Previous studies have shown that both seed yield and protein content of durum wheat produced under organic conditions are often $20 \%$ to $40 \%$ lower than those achieved under conventional conditions, probably due to insufficient nitrogen supply during the later growth stages (Mäder et al., 2007; Taylor and Cormack, 2002). Other traits, such as kernel weight and hectolitre weight, can affect the productivity and efficiency of flour milling, and therefore these provide good indications of grain quality (Murphy et al., 2007). In the present study, the organic cropping system produced lower protein content but higher seed weight and hectolitre weight (above the minimum threshold required: $80 \mathrm{~kg} \mathrm{hL}^{-1}$ ) than the conventional cropping system. Similar values of test weight were reported by Fagnano et al. (2012) in five durum wheat cultivars grown in a Mediterranean area. Therefore, according to Bilsborrow et al. (2013), it appears that the achieving of an acceptable hectolitre weight is a relatively minor issue in organic wheat production systems compared with the producing of high yields of grain with high protein content.

Under organic management conditions, increased grain yield was associated with early maturity. Furthermore, the high positive correlation between seed yield and protein content under the organic cropping system allows the identification of genotypes with good production potential and quality characteristics under suboptimal agronomic conditions. On the other hand, most of the examined traits showed imbalanced correlations among each other regarding the two management systems; for this reason, and as suggested by Mikò et al. (2014), they can be used in a separate organic wheat breeding approach.

A predominant importance of environmental factors, characterizing locations, and cropping seasons in the determination of durum wheat yield was reported by 
Bendjama et al. (2014) in a set of 23 cultivars from Algeria. Due to the significance of the $\mathrm{G} \times \mathrm{E}$ interaction, we further estimated the phenotypic stability for the seed yield using different stability statistics to identify genotypes that are adapted across the environments. The most commonly used stability parameters are regression coefficients and deviation mean squares. These are useful for measures of 'static' or 'biological' stability, which can also be an interesting trait for varietal recommendations. Nevertheless, this type of stability has often been ignored by wheat breeders, as it is almost always associated with minimal yield potential (De Vita and Maggio, 2006). Using a univariate approach (i.e., $b, S^{2} \mathrm{~d}, \mathrm{R}^{2}$ ) to evaluate 20 old and new durum wheat cultivars in 10 locations over 3 years, De Vita and Maggio (2006) reported that the breeding objectives that led to new varieties might have been very different. It appears that the modern durum wheat cultivars were specifically adapted to the most productive environments, showing better responsiveness to increased environmental fertility when compared with the old cultivars that were specifically adapted to poor environments (Alvaro et al., 2008a, b; De Vita et al., 2007b; Royo et al., 2007). In the present study, among the genotypes examined, the selection appears to be based on traits that influence high yield potential (i.e., 'Anco Marzio') or higher biological stability (i.e., 'Dylan', 'Iride'). However, in assessing the performance of genotypes in different environments, a multivariate approach appears to be more appropriate. In an AMMI model, the number of terms to be included cannot be specified a priori because many factors (e.g., crop management, germplasm, environmental conditions) can affect the degree of complexity of the best predictive model (Crossa et al., 1990). Thus, in the present study, the interaction of the 10 genotypes with the six environments was best predicted by the first two principal components. The biplot of the AMMI1 shows not only the mean yield of a variety, but also how it was achieved, whereas the two IPCAs reported in the AMMI2 biplot provide a good explanation of the data pattern (Mohammadi et al., 2010). The biplots identified fertile environments (e.g., for all years with conventional management, and for one year in organic management) and genotypes with high mean production and less $\mathrm{G} \times \mathrm{E}$ interaction (i.e., 'Iride', 'Saragolla'). These show that the interaction was also variable from year to year, probably because of the contrasting rainfall distributions. This indicates that in causing most of the variation of the grain yield, the years were highly informative to assess the performance of the genotypes in a specific site and under a defined crop management system.

Annicchiarico et al. (2006) and De Vita et al. (2010) reported that $\mathrm{R}^{2}, S^{2} \mathrm{~d}$, ASV and YSI are generally important in the determination of the comparative stability of the durum wheat genotypes. These four stability measurements identified 'Iride', 'Dylan', 'Duilio' and 'Saragolla' as the most stable varieties; among these, 'Iride' and 'Saragolla' also had good seed yield, while 'Anco Marzio' and 'Tirex' were narrowly adapted to specific environments. Although, according to Purchase et al. (2000), we found significant correlation between the stability measures ASV and $S^{2} \mathrm{~d}$, the ASV appears to be the most correct single method to describe the stability of the genotypes, because the genotype response to the environments is multivariate.

As shown by Murphy et al. (2007), several comparisons between organic and conventional farming systems rely primarily on modern cultivars that have been selected by plant breeders under conventional systems, and that might not be representative of the conditions present in organic farming. However, according to the results of the present study, the most popular cultivars of durum wheat used for conventional farming, 'Iride' and 'Saragolla', are also suitable for organic farming in the Mediterranean environments. Thus, as suggested by Bendjama et al. (2014), the cultivars 'Iride' and 'Saragolla' can also be used as cultivars to monitor for general adaptation and for stability of new promising entries to be tested.

\section{Materials and Methods}

\section{Plant materials}

Ten durum wheat cultivars were evaluated in the experimental fields of the Cereal Research Centre (CREACER) in Foggia (southern Italy) $\left(41^{\circ} 28^{\prime} \mathrm{N}, 1^{\circ} 34^{\prime} \mathrm{E} ; 76 \mathrm{~m}\right.$ a.s.1.), over three consecutive growing seasons (2011-2012, 2012-2013, 2013-2014): 'Anco Marzio', 'Aureo', 'Claudio', 'Duilio', 'Dylan', 'Iride', 'Saragolla', 'Simeto', 'Svevo', and 'Tirex'. These cultivars are currently grown all over Italy and represent a range of genotypes that are differentiating for earliness characteristics.

\section{Field trials}

The 10 durum wheat cultivars were grown under conventional (i.e., mineral fertilizers and chemical weed control) and organic (i.e., no fertilizers and no weed control) cropping systems. The organic and conventional fields were separated by buffer strips (minimum spacing, $8 \mathrm{~m}$ ), although they were otherwise located under similar microclimatic conditions with comparable soil properties, to minimize nonsystem specific variations. The trials were performed on a clay-loam soil (Typic Chromoxerert) with the following characteristics: $36.9 \%$ clay, $50.5 \%$ silt, $12.5 \%$ sand, $\mathrm{pH} 8$ (in $\mathrm{H}_{2} \mathrm{O}$ ), $15 \mathrm{mg} \mathrm{kg}^{-1}$ available $\mathrm{P}$ (Olsen method), $800 \mathrm{mg} \mathrm{kg}^{-1}$ exchangeable $\mathrm{K}\left(\mathrm{NH}_{4} \mathrm{Ac}\right)$, and $21 \mathrm{~g} \mathrm{~kg}^{-1}$ organic matter (Walkey-Black method). The field used for the organic experiment had been managed under organic farming for the previous 14 years and the experiment was repeated in the same field, but in different plots. For the conventional cropping system, the cultivars were sown after the fallow year, while for the organic cropping system the preceding crop was chick pea (Cicer arietinum L.), in all years. The land was ploughed, hoed and harrowed twice prior to planting. Sowing was performed on December 6, 2011, December 28, 2012, and December 11, 2013, at a seeding density of 350 viable seeds $\mathrm{m}^{-2}$. The experimental design used was split-plot with three replicates. The method of cultivation (organic vs. conventional) is the main factor, and the 10 genotypes were randomly assigned to the main plots, according to a randomized complete block design. Plots were $10 \mathrm{~m}^{2}$, with 8 rows that were $7.5 \mathrm{~m}$ long and $0.17 \mathrm{~m}$ apart. For the conventional cropping system, weed control was carried out at the end of tillering, using Buctril Universal (2,4-dichlorophenoxyacetic acid, 23.8\% [280 $\mathrm{g} \mathrm{L}^{-1}$ ] plus bromoxynil octanoate $23.8 \%$ [280 $\left.\mathrm{g} \mathrm{L}^{-1}\right]$ ) mixed with Axial (pinoxaden $5.05 \%\left[50 \mathrm{~g} \mathrm{~L}^{-1}\right]$ plus cloquintocet-mexyl $1.26 \%$ $\left.\left[12.5 \mathrm{~g} \mathrm{~L}^{-1}\right]\right)$. The fertilizer used at sowing was $200 \mathrm{~kg} \mathrm{ha}^{-1}$ $18 / 46$ fertiliser ( $18 \%$ elemental $\mathrm{N}, 46 \% \mathrm{P}_{2} \mathrm{O}_{5}$; by weight), and at plant tillering was $200 \mathrm{~kg} \mathrm{ha}^{-1} \mathrm{NH}_{4} \mathrm{NO}_{3}(26 \%$ elemental $\mathrm{N})$. For the organic cropping system, no chemical weed control or fertilizers were used.

The environmental data for the three growing seasons with the long-term (15-year) means are shown in Table 1. All of the climatic data were obtained from an on-site weather station. The maximum and minimum temperatures and total rainfall were similar for the first 2 years of the study, which 
showed a wider temperature range and a lower rainfall than the long-term means. The temperatures in the third year were more similar to the long-term means, although in 2014 there was a lot more rain during April and May than for the longterm means, and these conditions coincided with the end of stem elongation and with the grain filling period.

\section{Agronomic traits}

Heading time was recorded as the number of days from April 1 until the ears of $50 \%$ of the tillers had emerged from the flag-leaf sheaths by approximately half of their length (i.e., growth stage 55 in the Zadoks scale; Zadoks et al., 1974). Plant height $(\mathrm{cm})$ was measured during the milk waxy maturation stage, when the maximum height was achieved, from ground to the tip of the ear (excluding awns) on five main culms per plot. In each plot, the final harvest was performed early in June each year, after physiological maturity, on the six central rows, using a plot harvester. The grain yield $\left(\mathrm{t} \mathrm{ha}^{-1}\right)$ was determined and expressed at a $13 \%$ moisture level. Thousand-seed weight $(\mathrm{g})$ was calculated as the mean weight of five sets of 200 grains per plot. Test weight was measured on $250-\mathrm{g}$ samples per plot, using a Shopper Chondrometer equipped with a 1-L container. These data are reported in $\mathrm{kg} \mathrm{hL}^{-1}$, without reference to the moisture content. Protein content was determined on a sample of $500 \mathrm{~g}$ kernels, using the methodology of the near-infrared spectrometer (Infratec 1241 Grain Analyzer; Foss Electric Analytical A/S, Hillerød, Denmark).

\section{Statistical analysis}

Analysis of variance (ANOVA) was conducted for each environment (treatment per year) to test for significant differences among the cultivars, and homogeneity of error variance tests were conducted to determine whether the data from individual treatments could be pooled to evaluate the interactions using combined ANOVA. A linear model was used in which the cultivar and treatment factors were regarded as fixed effects, while the years and blocks were regarded as random effects. Significantly different means were separated at the 0.05 probability level using least significant difference tests. Furthermore, correlations of traits for the two management systems were determined on the basis of Pearson's correlation coefficients. The stability indices for seed yield were estimated for each cultivar. The parameters considered were: linear regression coefficient, $b$ (Finlay and Wilkinson, 1963); deviation from regression, $S^{2} \mathrm{~d}$ (Eberhart and Russell, 1966); coefficient of determination, $\mathrm{R}^{2}$ (Pinthus, 1973); AMMI stability value (ASV) (Purchase,1997); and yield stability index (YSI) (Mohammadi et al., 2010). AMMI analysis was performed as described by Zobel et al. (1988). Environments were defined by the cultivation-year combination. In total, data from six environments were available (two cultivation systems, 3 years). According to Farshadfar et al. (2011), to better understand the relationships and similarities and dissimilarities among the yield-stability statistics, principal component analysis (PCA) based on the rank correlation matrix was used. The statistical analyses were performed using two software programs: STATISTICA (StatSoft version 7.1; StatSoft, Inc., Tulsa, OK, USA) and R package Agricolae (version 1.2-1) (http://cran.rproject.org/web/packages/agricolae/index.html).

\section{Conclusions}

This study shows that seed yield and stability of genotypes across years is strongly affected by both farming systems and years, and the importance of $\mathrm{G} \times \mathrm{E}$ interactions was clearly shown. There is, therefore, the need to test durum wheat varieties in multiple trials to minimize crop failure, especially in low-fertility environments. However, it is possible to identify genotypes that were selected for conventional farming management that have high and stable yields and quality characteristics under organic farming conditions. These can be used to update the lists of varietal guidance for organic agriculture in Mediterranean environments.

\section{Acknowledgments}

This study was self-financed by the CREA (Council for Agricultural Research and Economics) within the scope of a larger project granted by the Italian Ministry of Agricultural, Food and Forestry Policies.

\section{References}

Alvaro F, Isidro J, Villegas D, Garcia del Moral LF, Royo C (2008a) Breeding effects on grain filling, biomass partitioning, and remobilization in Mediterranean durum wheat. Agron J. 100: 361-370.

Alvaro F, Isidro J, Villegas D, Garcia del Moral LF, Royo C (2008b) Old and modern durum wheat varieties from Italy and Spain differ in main spike components. Field Crops Res. 106: 86-93.

Annicchiarico P, Bellah F, Chiari T (2006) Repeatable genotype $\mathrm{x}$ location interaction and its exploitation by conventional and GIS-based cultivar recommendation for durum wheat in Algeria. Eur J Agron. 24: 70-81.

Araus JL, Slafer MP, Reynolds MP, Royo C (2002) Plant breeding and drought in C3 cereals: what should we breed for? Ann Bot. 89: 925-940.

Becker HC, Léon J (1988) Stability analysis in plant breeding. Plant Breed 101:1-23.

Bendjama A, Bouzerzour H, Benbelkacem A (2014) Adaptability of durum wheat genotypes (Triticum turgidum L. Var durum) to contrasted locations. Aust J Basic Appl Sci. 8(6): 390-396.

Bilsborrow P, Cooper J, Tetard-Jones C, Średnicka-Tober D, Barański M, Eyre M, Schmidt C, Shotton P, Volakakis N, Cakmak I, Ozturk L, Leifert C, Wilcockson S (2013) The effect of organic and conventional management on the yield and quality of wheat grown in a long-term field trial. Eur J Agron. 51:71-60.

Bulluck LR, Brosius M, Evanylo GK, Ristaino JB (2002) Organic and synthetic amendments influence soil microbial, physical and chemical properties on organic and conventional farms. Appl Soil Ecol. 19: 147-160.

Crossa J, Gauch HG, Zobel RW (1990) Additive main effects and multiplicative interaction analysis of two international maize cultivar trials. Crop Sci. 30: 493-500.

D'Egidio MG (2007) Overview on pasta in the world. Tecnica Molitoria Int 58: 92-97.

De Vita P, Maggio A (2006) Yield stability analysis in durum wheat: progress over the last two decades in Italy. Cereal Res Comm. 34: 1207-1213

De Vita P, Di Paolo E, Fecondo G, Di Fonzo N, Pisante M (2007a) No-tillage and conventional tillage effects on durum wheat yield, grain quality and soil moisture content in southern Italy. Soil Till Res. 92: 69-78. 
De Vita P, Li Destri Nicosia O, Nigro F, Platani C, Riefolo C, Di Fonzo N, Cattivelli L (2007b) Breeding progress in morpho-physiological, agronomical and qualitative traits of durum wheat cultivars released in Italy during the 20th century. Eur J Agron. 26: 39-53.

De Vita P, Mastrangelo AM, Matteu L, Mazzucotelli E, Virzì N, Palumbo M, Lo Storto M, Rizza F, Cattivelli L (2010) Genetic improvement effects on yield stability in durum wheat genotypes grown in Italy. Field Crops Res. 119: 6877.

Eberhart SA, Russell WA (1966) Stability parameters for comparing varieties. Crop Sci. 6: 36-40.

Fagnano M, Fiorentino N, D'Egidio MG, Quaranta F, Ritieni A, Ferracane R, Raimondi G (2012) Durum wheat in conventional and organic farming: yield amount and pasta quality in Southern Italy. Sci World J. Article ID 973058, 9 pages doi:10.1100/2012/973058.

Farshadfar E, Mahmodi N, Yaghotipoor A (2011) AMMI stability value and simultaneous estimation of yield and yield stability in bread wheat (Triticum aestivum L.). Aust J Crop Sci. 5: 1837-1844.

Finlay KW, Wilkinson GN (1963) The analysis of adaptation in a plant breeding programme. Aust J Agric Res. 14: 742754.

Kramer SB, Reganold JP, Glover JD, Bohannan BJ, Mooney HA (2006) Reduced nitrate leaching and enhanced denitrifier activity and efficiency in organically fertilized soils. Proc Natl Acad Sci USA. 103: 4522-4527.

Lammerts van Bueren ET, Jones SS, Tamm L, Murphy KM, Myers JR, Leifert C, Messmer MM (2011) The need to breed crop varieties suitable for organic farming, using wheat, tomato and broccoli as examples: A review. Wagen J Life Sci. 58: 193-205.

Mader P, Hahn D, Dubois D, Gunst L, Alföldi T, Bergmann H, Oehme M, Amadò R, Schneider H, Graf U, Velimirov A, Fließbach A, Niggli U (2007) Wheat quality in organic and conventional farming: results of a 21 year field experiment. J Sci Food Agr. 87(10): 1826-1835.

Mikó P, Löschenberger F, Hiltbrunner J, Aebi R, Megyeri M, Kovács G, Molnár-Láng M, Vida G, Rakszegi M (2014) Comparison of bread wheat varieties with different breeding origin under organic and low input management. Euphytica. 199: 69-80.

Mohammadi R, Haghparast R, Amri A, Ceccarelli S (2010) Yield stability of rainfed durum wheat and GGE biplot analysis of multi-environment trials. Crop Pasture Sci. 61: 92-101.

Murmu K, Swain DK, GhoshBC (2013) Comparative assessment of conventional and organic nutrient management on crop growth and yield and soil fertility in tomato-sweet corn production system. Aust J Crop Sci. 7(11): 1617-1626.

Murphy KM, Campbell KG, Lyon SR, Jones SS (2007) Evidence of varietal adaptation to organic farming systems. Field Crops Res. 102 (3): 172-177.

Pinthus MJ (1973) Estimate of genotypic value: A proposed method. Euphytica. 22: 121-123.

Purchase JL (1997) Parametric analysis to describe $\mathrm{G} \times \mathrm{E}$ interaction and yield stability in winter yield. Ph.D Thesis. Department of Agronomy, Falculty of Agriculture, University of Orange Free State, Bloemfontein, South Africa. 4-83.

Purchase JL, Hatting H, Van Deventer CS (2000) Genotype $\times$ environment interaction of winter wheat ( $T$. aestivum) in South Africa: stability analysis of yield performance. S Afr J Plant Soil. 17(3): 101-107.
Quaranta F, Amoriello T, Aureli G, Belocchi A, Bentivenga G, D'Egidio MG, Melloni S, Camerini M (2010) Grain yield, quality and deoxinyvalenol (DON) contamination of durum wheat (Triticum durum Desf.): results of national networks in organic and conventional cropping systems. Ital J Agron. 5: 361-374.

Ray DK, Gerber JS, MacDonald GK, West PC (2015) Climate variation explains a third of global crop yield variability. Nat Commun. 6: 1-9.

Royo, C, Álvaro F, Martos V, Ramdani A, Isidro J, Villegas D, García del Moral LF (2007) Genetic changes in durum wheat yield components and associated traits in Italian and Spanish varieties during the 20th century. Euphytica. 155: 259-270.

Stagnari F, Onofri A, Codianni P, Pisante M (2013) Durum wheat varieties in $\mathrm{N}$-deficient environments and organic farming: a comparison of yield, quality and stability performances. Plant Breed. 132: 266-275.

Taylor BR, Cormack WF (2002) Choices of species and varieties. In: Younie D, Taylor B, Welch JP, Wilkinson JM (eds) Organic cereals and Pulses. Lincoln, Chalcombe Publications, chapter 2, pp. 9-28.

Trewavas A (2004) A critical assessment of organic farmingand food assertions with particular respect to the UK and the potential environmental benefits of no-till agriculture. Crop Prot 23: 757-781.

Wheeler SA (2008) What influences agricultural professionals'views towards organic agriculture? Ecol Econom. 65:145-154.

Willer H, Yussefi M (2007) The World of Organic Agriculture. Statistics and Emerging Trends. 9th edition IFOAM, Bonn, Germany \& FiBL, Frick, Switzerland.

Wolfe MS, Baresel JP, Desclaux D, Goldringer I, Hoad S, Kovacs G, Löschenberger F, Miedaner T, Østergård H, Lammerts van Bueren ET (2008) Developments in breeding cereals for organic agriculture. Euphytica. 163:323-346.

Zadoks JC, Chang TT, Konzak CF (1974) A Decimal Code for the Growth Stages of Cereals. Weed Res 14:415-421.

Zobel RW, Wright MG, Gauch HG (1988) Statistical analysis of yield trial. Agron J. 80: 388-393. 